Cleide Maria de OLIVEIRA*

Resumo

O artigo faz leitura direcionada de um corpus de poemas selecionados de Carlos Drummond de Andrade, no qual, sem pretensões de uma interpretação totalizante de sua obra, busca a compreensão de temas, assuntos e figuras afins à filosofia existencialista, conforme disseminada por Jean-Paul Sartre. A conclusão a que se chega é a de que, embora não seja possível identificar influências diretas do existencialismo na poesia de Drummond, nota-se temas e abordagens comuns entre ele e a sua poesia, principalmente no que diz respeito à compreensão de uma radical temporalidade própria ao homem aliada ao exílio da liberdade, o que o torna persona de seu tempo e construtor de si mesmo.

Palavras-chave: Carlos Drummond de Andrade. Existencialismo. Poesia. Jean-Paul Sartre.

Definir a especificidade da atitude filosófica como um espantar-se diante daquilo que o senso comum julgaria simples é uma tradição que remonta à Aristóteles e é retomada por Heidegger (2001, p. 229) quando afirma que "É preciso espantar-se diante do simples e assumir esse espanto como morada”. Tal espanto não é acessório nem supérfluo, como seria o caso se fosse apenas um estímulo ao pensamento, mas é arkhé e perpassa o itinerário filosófico. Em texto sobre a poesia de Hölderlin (2001), Heidegger diz que a poesia apela e resguarda o estranho de tudo aquilo que se mostrou aparentemente corriqueiro, com o intuito de velar por isso que vem até nós como desconhecido, inquietante e não familiar. O poeta é esse capaz de construir uma linguagem livre das tentações do conhecimento

Professora de Língua e Cultura Brasileira no Centro Federal de Educação Tecnológica de Minas Gerais/ CEFET-MG, Belo Horizonte, Minas Gerais, Brasil.

E-mail: cleideoliva@cefetmg.br Orcid iD: https://orcid.org/0000-0002-3586-332X 
propositivo e dos ditames da lógica, em uma conversa com o pensamento que busca "evocar a essência da linguagem para que os mortais aprendam novamente a morar na linguagem" (HEIDEGGER, 2003, p. 28, grifo do autor), afirmativa algo sibilina que, poeticamente, nos fala de um tempo utópico no qual não havia fissuras entre ser e dizer-se ${ }^{1}$. Isso que se retrai ao homem, não obstante "sempre se mostre", esse resíduo do real que subjaz como silêncio na nossa fala cotidiana, conforme Heidegger, é a própria matéria da poesia, sustentada pela proximidade do poeta com o sagrado, afinal, "O poeta está exposto ao relâmpago dos deuses" (HEIDEGGER, 2006, p. 105). Pensar a relação entre poesia e filosofia nessa chave de Heidegger é rentável porque permite assinalar outras proximidades que não apenas as referências diretas a escolas de pensamento ou o uso explícito pelo poeta de um linguajar técnico dessa ou daquela filosofia. Permite-nos perceber em uma gama de poetas, dos mais diversos estilos e nacionalidades, esse espanto primordial que alimenta o autêntico discurso filosófico, dos quais deseja-se, neste artigo, destacar Carlos Drummond de Andrade, cujas reflexões filosóficas permeiam sua poesia. Tome-se como exemplo o seguinte verso: "As coisas. Que tristes são as coisas consideradas sem ênfase" (Rosa do povo), no qual reside densa meditação sobre a tensa relação do homem com o mundo/realidade, ao qual ele tanto empresta sentido quanto é pelo mundo significado (afinal, conforme mandamento da sociedade do consumo, ter é ser).

Poeta complexo, multifacetado, Drummond transita entre temas e motivos dos mais diversos - desde aqueles do cotidiano, da família, da infância recuperada pela memória amorosa, passando pela poesia engajada e comprometida em denunciar "a ração diária de erro" (A flor e a náusea, Rosa do povo) de um mundo burocrata e mecânico, e pela poesia especulativa - presente em todas as fases de sua obra - que insiste em duvidar das grandes metanarrativas - veja-se: "O amor não nos explica. E nada basta, \nada é de natureza assim tão casta \que não macule ou perca

Nosso intuito não é nos deter no pensamento complexo de Heidegger, mas apenas em alguns trechos de suas obras nos quais ele expressa uma relação entre poesia e pensamento. 
sua essência \ao contato furioso da existência” (Relógio do Rosário, Claro enigma) -, chegando ao "escândalo" de uma surpreendente poesia erótica que, entre outras estripulias, tece uma deliciosa elegia à bunda. É, pois, com Drummond que tencionamos caminhar neste artigo que busca articulações entre a poesia e a filosofia, notadamente desse com a filosofia de cunho existencialista, cuja presença em sua vasta obra é uma dessas obviedades que dispensam argumentação além de uma breve folheada em alguns de seus livros e poemas - em especial em O Sentimento do mundo (1940), José (1942) e A rosa do povo (1945), dentre outros. É bem verdade que JeanPaul Sartre - o maior garoto propaganda do existencialismo - gozou de grande popularidade nos anos 40 a 60 e teve grande influência na cultura e contracultura brasileira (MONTEIRO, 2007), tornando-se referência filosófica e política para muitos intelectuais nacionais, transformandose em uma "moda" na música, nas artes e na literatura. Cançado (2012) lembra em sua biografia de Drummond que esse era leitor de Kierkegaard - filósofo que seria uma espécie de precursor do existencialismo sartreano -, de modo que, se é talvez arriscado fazer afirmação de uma influência direta, há que se pensar, com Prado Jr. $(2014)^{2}$, em um certo espírito da época (Zeitgeist) comum aos dois autores:

São vários os autores de língua portuguesa cuja literatura, sendo militante, pode ser comparada, com proveito, com a obra de Sartre. Quero, no entanto, limitar-me apenas a Carlos Drummond de Andrade, cuja obra não entrega todo o seu segredo sem alguma referência a seu contemporâneo francês. É surpreendente a coincidência temporal da emergência de temas, escolhas teóricas, práticas e estilísticas entre os dois autores, sem que se possa falar de influência: certamente Sartre não leu Drummond nos fins da Segunda Grande Guerra, nos textos de poesia e prosa que antecipam as páginas com que o filósofo francês lançaria sua revista, assim como nos da retomada sistemática dessas propostas em “Qu'est-ce que la littérature?”. (PRADO JR., 2014, p. 1, grifo nosso).

2 A entrevista é anexo da tese de dissertação de mestrado de Monteiro (2007). 
Bosi (2006), em comentário à obra de Drummond, dirá por exemplo que há um existencialismo niilista nesta poesia, que apareceria codificado em alguns poemas, e de forma plena em outros. Sant'Anna (1992) também aponta traços de um pensamento existencialista em Drummond, em especial a figura do gauche, em permanente desacordo com o mundo; muito embora tome o cuidado de negar que o poeta tenha aderido a essa ou aquela filosofia. Com idêntico cuidado de absterse de afirmações contundentes sobre a relação entre Drummond e o existencialismo, pretende-se, neste ensaio, fazer uma leitura direcionada de um corpus de poemas de Carlos Drummond de Andrade, no qual, sem pretensões de uma interpretação totalizante de sua obra, se perseguirá a compreensão de temas, assuntos e figuras afins à filosofia existencialista, conforme disseminada por Jean-Paul Sartre.

"É NECESSÁRIO VOLTAR ÀS COISAS MESMAS": FENOMENOLOGIA E EXISTENCIALISMO

É notória a dívida do existencialismo sartreano para com a fenomenologia de Edmund Husserl (1859-1938). O encontro de Sartre com o pensamento de Husserl é narrado em sua biografia: um antigo colega da Escola Normal Superior de Paris, em uma reunião de amigos, afirma a Sartre que se ele fizesse fenomenologia poderia filosofar sobre as garrafas de vinho sobre a mesa. A partir dessa provocação, Sartre teria se interessado pela fenomenologia de Husserl e lido a única publicação disponível, na França, sobre esse filósofo alemão: Teoria da intuição na fenomenologia de Husserl, de Emmanuel Levinas (1930). Mais tarde, Sartre escreveu dois textos curtos sobre Husserl: Uma ideia fundamental da fenomenologia de Husserl: a intencionalidade, e A transcendência do ego, ambos publicados em 1933.

De forma simplificada, poderíamos dizer que a fenomenologia é, para usar a fórmula conhecida, um método de investigação filosófica que pretende "uma volta às coisas mesmas", a partir da tentativa de superar tanto o idealismo quanto o realismo filosófico, pois convicta de que 
tanto em um quanto em outro sistema de pensamento não se teria um conhecimento verdadeiro da realidade fenomênica, e sim uma projeção do sujeito no mundo, sujeito que acaba recolhendo das coisas apenas o que nelas depositou. A fenomenologia põe sob suspeita a possibilidade do conhecimento, e busca estabelecer quais são as condições de acesso às coisas, e as relações entre os fenômenos e a consciência. Postula que a interioridade do sujeito não seria um núcleo duro - como pensava, por exemplo, Descartes - mas sim flexível, sendo antes um tender para. $\mathrm{O}$ "eu" se encontra com o mundo, e é nessa relação que se constitui o conhecimento, daí a importância do conceito de intencionalidade, que seria o modo próprio de funcionamento da consciência, sempre consciência de alguma coisa, um lançar-se sobre as coisas: "clara como um grande vento, não há nada nela, salvo um movimento para fugir de si, um deslizamento para fora de si" (SARTRE, 1987, p.106). Assim, uma consciência não é uma coisa entre outras coisas, não é uma substância, ou uma alma, é "pura atividade, o ato de construir essências ou significações, dando sentido ao mundo das coisas” (CHAUí, 2003, p. 202). Conforme Leopoldo e Silva (2013), a recepção da fenomenologia no pensamento de Sartre irá "exagerar" a noção de intencionalidade para enfatizar o movimento/ação para fora de si mesmo, para as coisas, a rua, os outros. Entendendo que o primeiro passo da filosofia autêntica é expulsar as coisas da consciência, negando-a enquanto coisa, Sartre defini o eu como um movimento para chegar a si mesmo e a consciência como um "moverse para" que vai buscar o "maciço de si" fora de si mesmo: "A consciência seria por definição explosão para fora de si mesma - logo, não pode ser em nenhum caso assimilação do mundo" (BERNARDO, 2002, p. 84). Por outro lado, a intencionalidade é uma doação de sentido, atribuição de valores e de possibilidades de recepção.

Aí encontram-se os princípios básicos do existencialismo sartreano: se o indivíduo é um processo de ser, se a realidade humana não tem uma essência predeterminada, mas é um constante transcender-se, somos aquilo que ainda não somos, projeto (ação de lançar-se para fora de si) em construção permanente, de onde a máxima: somos liberdade, estamos 
condenados a ser livres. A consequência mais significativa dessa afirmação é ética: o homem é aquilo que fará de si mesmo - mas isso não nos diz o que ele é, não nos dá uma essência preexistente, senão constata que ele é um permanente vir a ser. Há um compromisso que nos une enquanto projetos que se tocam e se autodeterminam, de tal modo que a liberdade sartreana só pode ser compreendida a partir da noção de intersubjetividade, que salva o eu de cair em um abismo solipsista:

Através do penso, contrariamente à filosofia de Descartes, contrariamente a filosofia de Kant, nós nos apreendemos a nós mesmos perante o outro, o outro é tão verdadeiro para nós quanto nós mesmos. Assim, o homem que se alcança diretamente pelo cogito descobre também todos os outros, e descobre-se como sendo a própria condição de sua existência. (SARTRE, 1987, p. 33).

Quando agimos escolhemos uma ação, dentre todas possíveis, e tornamos essa ação um valor universalizável. Por exemplo, se eu decido não votar nas eleições para presidente, decido que a participação política é irrelevante ou ineficaz como exercício de cidadania, decido que o sistema democrático vigente pode subsistir sem a participação de cada um de nós, ou então que é desnecessário que ele subsista. Há, portanto, uma importante tomada de posição ética no existencialismo:

[...] o primeiro passo do existencialismo é o de pôr todo homem na posse do que ele é, de submetê-lo à reponsabilidade total de sua existência. Assim, quando dizemos que o homem é responsável por si mesmo, não queremos dizer que o homem é apenas responsável pela sua estrita individualidade, mas que ele é responsável por todos os homens. [....] Ao afirmarmos que o homem se escolhe a si mesmo, queremos dizer que cada um de nós se escolhe, mas queremos dizer também que, escolhendo-se ele escolhe todos os homens. (SARTRE, 1987, p. 11-12, grifo nosso).

A responsabilidade de escolher-se, e escolhendo-se escolher o homem, gera angústia, conceito importante em Sartre que, assumindo uma 
postura ateia, nega a existência de Deus e leva às últimas consequências essa negação. Citando o célebre aforismo de Dostoievski - "Se Deus não existe tudo é permitido" - Sartre (1987, p. 18) conclui: “[...], por conseguinte, o homem está desamparado porque não encontra nele próprio nem fora dele nada a que se agarrar. Para começar, não encontra desculpas”. Por outro lado, o homem que "inventa determinismos" (p. 40), age de má fé, tentando driblar sua própria consciência, é alguém que não assume a responsabilidade de "inventar valores" pois, se a vida não tem sentido a priori e, “[...] já que eliminamos Deus Nosso Senhor, alguém terá que inventar os valores” (SARTRE, 1987, p. 45).

Muitos dos questionamentos que alimentam o existencialismo - inclusive a questão mais basilar da intencionalidade herdada da fenomenologia - irão aparecer na poesia de Drummond, de forma mais ou menos evidente. A intenção deste ensaio não é arriscar uma interpretação totalizante do impacto do existencialismo em sua densa obra poética, e sim a ambição mais modesta de mostrar a recorrência de temas afins ao existencialismo (e eventualmente à fenomenologia), além de ensaiar uma leitura localizada do corpus poético selecionado. Passemos, portanto, a Drummond.

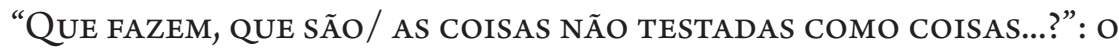
MUNDO SOB SUSPEITA

O poema "A suposta existência" (Paixão medida) é certamente um dos mais filosóficos e intrigantes de Drummond, na medida em que atualiza a discussão antiga entre duas concepções de mundo e realidade, e as possibilidades de apreensão cognitiva desses, ou seja, dois grandes modos de compreensão da relação entre sujeito e objeto de conhecimento: o realismo e o idealismo. Por realismo podemos entender, grosso modo, as posições filosóficas que pretendem haver a existência objetiva da realidade externa "como uma realidade racional em si e por si mesma" (CHAUÍ, 2003, p. 68), bem como afirmam que a realidade externa ao nosso pensamento é racional e passível de conhecimento justamente por ser racional. Já as 
posições chamadas idealismo postulam uma diferença entre a realidade e o conhecimento que dela podemos alcançar, ou seja, que "Não podemos saber nem dizer se a realidade externa é racional em si, pois só podemos saber e dizer que ela é racional para nós, isto é, por meio de nossas ideias" (CHAUÍ, 2003, p. 68, grifo da autora). É justamente a esse debate entre realismo e idealismo que a fenomenologia quer responder quando afirma ser necessário "voltar às coisas mesmas", compreendendo que elas não nos "aparecem", mas "são vividas", experimentadas como fenômenos significativos, ou seja, não são realidades independentes da consciência, ou meras abstrações da mesma consciência, mas experiências de doação de sentido nas quais estão implicados intimamente mundo e consciência.

Tais questionamentos alimentam o acima citado poema:
Como é o lugar
Quando ninguém passa por ele?
Existem as coisas
Sem ser vistas?

Há um mundo independente do olhar que sobre ele recai? E o que é esse mundo se não o vestimos com as roupas de nossa cultura e determinações?

Que fazem, que são

As coisas não testadas como coisas?

Pensar um mundo descoisificado ${ }^{3}$ não é empreitada fácil no contemporâneo, quando vivemos soterrado por coisas aparentemente tão úteis e necessárias quanto insignificantes, e por isso descartáveis. Esse é um tema presente em Drummond, que em um de seus mais famosos

\footnotetext{
3 Manoel de Barros é um poeta notável nesse projeto de "desinventar" objetos, poetizando um mundo reificado. Um exemplo do que se quer dizer com "descoisificação" é dado em um de seus poemas: "Desinventar objetos. O pente, por exemplo. / Dar ao pente funções de não pentear. / Até que ele fique à disposição de ser uma begônia. Ou uma gravanha. / Usar as palavras que ainda não tenham idioma”.
} 
poemas ("A flor e a náusea") declara: "As coisas. Que tristes são as coisas, consideradas sem ênfase", versos em que se intui a obscuridade inerente a um mundo sem a ênfase que o sujeito lhe dá - a intencionalidade, para usar palavras de Husserl. Ainda nesse livro (Rosa do povo), ele aconselha "não tires poesia das coisas" - pois essa "elide sujeito e objeto", enfatizando esse aspecto "erótico" da poesia já assinalado por Octávio Paz e Georges Bataille", mas aparentemente contradizendo palavras do belo "Canto ao homem do povo Charlie Chaplin”, no qual as coisas são novamente retomadas como matéria de poesia, sendo exatamente sua "loquacidade" proporcional à obscuridade que carregam em si.

E falam as flores que tanto amas quando pisadas,

Falam os tocos de vela, que comes na extrema penúria, falam a mesa, os botões,

Os instrumentos do ofício e as mil coisas aparentemente fechadas, Cada troço, cada objeto do sótão, quanto mais obscuros mais falam.

As coisas falam, sabem se esconder e se esgueirar por detrás das nossas lentes curiosas,
A casa tem muitas gavetas
E papéis, escadas compridas,
Quem sabe a malícia das coisas,
Quando a matéria se aborrece?
(Retrato de família, Rosa do povo).

4 O filósofo Georges Bataille e o poeta Octávio Paz, apesar das singularidades próprias a cada um, compartilham a ideia de um erotismo das palavras: no primeiro, "A poesia conduz ao mesmo ponto como cada forma do erotismo; conduz à indistinção, à fusão dos objetos distintos. Ela nos conduz à eternidade, à morte, e pela morte à continuidade..." (BATAILLE, 1987, p. 23); no segundo "A verdade é que na experiência do sobrenatural, como na do amor e na da poesia, o homem se sente arrancado ou separado de si. E a essa primeira sensação de ruptura segue-se outra de total identificação com aquilo que parecia alheio e no qual nos fundimos de tal maneira que já não é distinguível e separável de nosso próprio ser. Por que não pensar então que todas essas experiências têm por centro algo mais antigo que a sexualidade, a organização econômica ou social, ou qualquer outra "causa”. (1982, p.163-164). Em ambos os autores, procuramos enfatizar esse apagamento das fronteiras entre sujeito e objeto a que o verso de Drummond faz alusão, e é próprio dos movimentos eróticos. 
E, no enigmático poema "Noite na repartição" (Rosa do povo), um drama poético que põe em cena as dores e dissabores dos bichos e coisas que compartilham com um oficial administrativo a noite em uma repartição pública, o lema "Que cada coisa seja uma coisa bela” é imperativo que instaura novamente a paz entre todos e garante subitamente a condição humana ao burocrata queixoso.

Os trechos citados, todos do marcante livro $A$ rosa do povo, não deixam entrever uma forma unívoca de pensar o relacionamento com as coisas, cujo significado e beleza, ora depende da "ênfase", do sentido conferido pelo homem, ora são fruto de certa "malícia" inerente ao mundo só aparentemente pacífico das coisas. A mesma ambiguidade aparece no poema "A suposta existência”, em análise, veja-se:

Existe o mundo

Apenas pelo olhar

Que o cria e lhe confere

Espacialidade?

A essa possibilidade idealista, opõe-se outra, de um realismo encantador:

Ou tudo vige

planturosamente, à revelia

de nossa judicial inquirição

e esta apenas existe consentida

pelos elementos inquiridos?

A opção escolhida parece ser a de uma espécie de construtivismo, no qual sujeito e mundo se implicam mutuamente, mas a balança pende de forma desigual para um protagonismo "do sumo real" em detrimento das "peripécias" humanas:

Será tudo talvez hipermercado

de possíveis e impossíveis possibilíssimos

que geram minha fantasia de consciência 
enquanto

exercito a mentira de passear

mas passeado sou pelo passeio,

que é o sumo real, a divertir-se

com esta bruma-sonho de sentir-me

e fruir peripécias de passagem?

Não me parece gratuita a repetição de palavras que se encontram no campo semântico da ilusão ou imaginação, veja-se: "fantasia de consciência", "mentira de passear", "bruma-sonho". Enfatiza-se o aspecto ficcional dessa construção que é o homem, aturdido ante tantos possíveis, condenado que é a decidir-se por ações concretas, em situações concretas e com consequências também concretas. Mas, nesse poema, para que o homem se assuma agente de si próprio é preciso rebelar-se contra o "mundo inventor":
Eis se delineia
espantosa batalha
entre o ser inventado
e o mundo inventor.

Assim, tendo-se escolhido a opção de um realismo enfraquecido, fala-se de um conflito existencial que, pelo menos nesse poema (que, lembremos, foi publicado em 1980, bem após a moda existencialista ter se acabado), é resolvido com a adesão a alguns determinismos, em evidente oposição ao imperativo sartreano de que "somos condenados à liberdade".

\author{
Sou ficção rebelada \\ contra a mente universa \\ e tento construir-me \\ de novo a cada instante, a cada cólica, \\ na faina de traçar \\ meu início só meu \\ e distender um arco de vontade \\ para cobrir todo o depósito \\ de circunstantes coisas soberanas
}


Se o homem é uma ficção, é também um rebelde que contra a "mente universa" busca "distender um arco de vontade" que se sobreponha a "circunstantes coisas soberanas". Atenua-se a noção de liberdade na medida em que o enquadramento circunstancial no qual se encontra o sujeito é "soberano", não obstante haja um projeto existencial singular que alimente esse mesmo sujeito ("meu início só meu”).
A guerra sem mercê, indefinida, prossegue, feita de negação, armas de dúvida, táticas a se voltarem contra mim, teima interrogante de saber se existe o inimigo, se existimos ou somos todos uma hipótese de luta ao sol do dia curto em que lutamos.

A inicial suspeita em relação à realidade circunstante atinge à própria definição do humano, reduzindo as possibilidades de existência a uma "hipótese de luta”. Como mencionado, esse poema é posterior à moda existencialista, e alguns pressupostos sartreanos, como a radical liberdade com que o homem se autodetermina, são enfraquecidos. Em outros poemas, fica bem explícita a temática comum ao existencialismo, inclusive com a consequente assunção do eu lírico enquanto ser que se constitui em relação ao horizonte da morte, ou "composição/que um dia se chamou Carlos Drummond de Andrade" ("Os últimos dias", Rosa do povo), vida aos outros legada que, quando finda, leva consigo "um certo modo de ver" (Desfile, Rosa do povo). Dessa forma, o entrelaçamento de uma dúvida radical em relação ao mundo fenomênico liga-se à dúvida sobre a constituição do humano e o sentido dessa frágil arquitetura - "Mas que coisa é o homem?", é pergunta reiterada no poema "Especulações em torno da palavra homem" - e, como uma constatação dolorosa de aporia, chega-se ao poema "José” (José), no qual e eu lírico é insistentemente questionado em relação ao "para onde" de seu estar-no-mundo. Mas 
a angústia de saber-se único responsável pelos equívocos resultados dessa construção atenua-se no belo poema "Os últimos dias", no qual a informação repetida é a de que "tudo, mas tudo é nosso irmão", de modo que se pode esperar por aquela hora indesejada das gentes sem negar-se enquanto composição na qual a partilha de sentido dá o tom e a forma. Leiamos esses poemas aludidos.

“E AGORA, JosÉ?”

Que coisa é, como se faz, quanto vale, como morre, quando morre, por que vive, por que mente, para que serve o homem são as perguntas inquietantes que recaem sobre o leitor desavisado do poema "Especulações em torno da palavra homem" (Vida passada a limpo). Note-se que são especulações em torno da palavra, e não da coisa homem, o que parece reforçar a busca de algo que poderíamos chamar de "essência" humana, caso o poema não terminasse com outra pergunta, ainda mais assombrosa: "Mas existe o homem?” Não há respostas cabíveis - ou, a pluralidade de respostas para a pergunta sobre o que é o homem invalida a escolha de uma delas - e isso é reiterado estilisticamente no poema que opera com alternativas possíveis elaboradas também como perguntas, por exemplo, à questão "Quanto vale o homem?”, tem-se as seguintes possibilidades, que se auto anulam:

Menos, mais que o peso?

Hoje mais que ontem?33

Vale menos, velho?

Vale menos, morto?

Menos um que outro,

Se o valor do homem

É medida de homem?

Por fim, a pergunta última "Que milagre é o homem?" é respondida com a dúvida perplexa "Mas existe o homem?", questionamento no qual parece ressoar a máxima existencialista, já mencionada, de que na espécie humana a existência precede a essência, ou seja, ao contrário de uma cadeira, 
ou de um celular, cuja essência se confunde com sua finalidade, e essa está explicita no uso que é dado a esses objetos, ou então no caso dos animais, colados na natureza de forma a tornar impossíveis comportamentos que não estejam inscritos no instinto ancestralmente herdado de seus pais, o homem é lançado no mundo sem cordas de segurança, sem apoios metafísicos ou valores preexistentes. Ele precisa construir-se como quem desenha uma paisagem ou uma figura, sem rascunhos, inventando um modo idiossincrático de ser e estar no mundo e, ao fazê-lo, elegendo comportamentos como desejáveis e valores como universais.

Em poema anterior a esse, a questão da angústia existencial ante a responsabilidade de "escolhendo-se, escolher o homem" (SARTRE, 1987, p. 13) é dramatizada na persona de um José sem sobrenome, em poema homônimo (J). Um dos poemas mais famosos de Drummond, que virou ditado popular ante uma situação de aporia, se inicia com o elencar de eventos que falam de finitude e acabamento, descrevendo uma situação progressiva de solidão na qual se insere o anônimo José, a quem é dirigida a pergunta fatal:

E agora, José?

A festa acabou,

A luz apagou,

O povo sumiu,

A noite esfriou,

E agora, José?

Você que é sem nome,

Que zomba dos outros,

Você que faz versos,

Que ama, protesta?

E agora, José?

Após ter sido feita uma paradoxal tentativa de delimitação de José, em que o nome comum é circunscrito por ações que pouco lhe determinam, confundido que está com uma multidão de outros que "amam e protestam”, há uma nova tentativa de adjetivar seu estar-no-mundo, em 
uma demarcação negativa que lembra o método apofático ${ }^{5}$, pois acentua coisas que ele não tem, coisas que não pode fazer e esperanças fracassadas, num encaminhamento para os versos finais que reiteram o fim presente na primeira estrofe:

\author{
Está sem mulher, \\ Está sem discurso, \\ Está sem carinho, \\ Já não pode beber, \\ Já não pode fumar, \\ Cuspir já não pode, \\ A noite esfriou, \\ $\mathrm{O}$ dia não veio, \\ $\mathrm{O}$ bonde não veio, \\ $\mathrm{O}$ riso não veio, \\ Não veio a utopia, \\ E tudo acabou \\ E tudo fugiu \\ E tudo mofou, \\ E agora, José?
}

5 O método apofático é um procedimento linguístico que encontra na mística apofática e na teologia negativa seu modelo, seu discurso se articula a partir de um imperativo e uma impossibilidade: dizer aquilo que não pode ser dito, dizer o inefável. Para tanto, os discursos apofático "originais", quer dizer, religiosos, procedem por meio de negações dos atributos/predicativos divinos, - vai-se da negação (remoção) dos nomes mais simples e humildes até um além categorial, no Inefável em que brilham as trevas divinas (SANTOS, 2004). Por outro lado, a contemporaneidade se caracteriza pela forte presença dos discursos negativos/apofático no campo da literatura e filosofia, essa é a opinião de Franke (2007), que organizou uma coletânea de discursos apofáticos desde os clássicos até os tempos contemporâneos. Para Franke (2007), a apofática se caracteriza principalmente por ser uma experiência de resistência da linguagem que nasce em momentos culturais nos quais há um colapso dos discursos de autoridade. A contemporaneidade seria, devido à absoluta crise de confiança no logos, uma época particularmente propícia ao surgimento desses discursos, que se caracterizariam por serem ataques à pretensão representativa da linguagem e tentativas de desestabilização das expectativas da linguagem como fundo literal/superfície figurativa. Para o autor, o indizível se mostra nos textos contemporâneos como os limites de uma opacidade intrínseca a todo discurso, uma inevitável não inteligibilidade no dizível, desta forma, "a experiência da apofática, como uma experiência daquilo que não pode ser dito, é essencialmente linguística: a experiência ela mesma é intrinsecamente uma experiência de fracasso da linguagem" (FRANKE, 2007, p. 3). 
A terceira estrofe repete a pergunta-título e também lista "posses” idiossincráticas de José - reforçada a ideia de singularidade no possessivo "seu/sua" - e terminam reconduzindo o leitor à pergunta mote - E agora? - e a uma consequente aporia. $\mathrm{O}$ que fazer com coisas, sentimentos e desejos quando se está em situação limite, e José está em uma situação limite, ainda que corriqueira: diante da finitude expressa nos primeiros versos e retomada na segunda estrofe ("A festa acabou, /a luz apagou/ o povo sumiu, / a noite esfriou...”)

E agora, José?

Sua doce palavra,

Seu instante de febre,

Sua gula e jejum,

Sua biblioteca,

Sua lavra de ouro,

Seu terno de vidro,

Sua incoerência,

Seu ódio - e agora?

A quarta estrofe continua a compor esse cenário de sufocamento e imobilidade, elencando possibilidades de fuga verossímeis que são interditas por eventos surrealistas:

Com a chave na mão

Quer abrir a porta,

Não existe porta;

Quer morrer no mar,

Mas o mar secou;

Quer ir para Minas,

Minas não há mais.

José, e agora?

Nessa altura do poema temos a repetição da conjunção condicional "se" em seis dos oito versos da quinta estrofe, note-se que as conjunções estão sem a sua contraparte argumentativa - "se isso" = "aquilo" - o que 
pode tanto indicar que as possíveis consequências são ilimitadas como que não há nenhuma possibilidade de escolha. Novas possibilidades - de que? Não se sabe - se abrem para José, mas todas elas são barradas pela constatação de José "ser duro".

Se você gritasse,

Se você gemesse,

Se você tocasse

A valsa vienense,

Se você dormisse,

Se você cansasse,

Se você morresse...

Mas você não morre,

Você é duro, José!

Os versos finais do poema enfatizam a solidão existencial de José: sem apoios metafísicos (teogonia), sem um estar-no-mundo confortável (parede nua), sem rotas de fuga (cavalo preto) José apenas marcha, sem que ele, ou o leitor, saiba para onde.

Sozinho no escuro

Qual bicho-do-mato,

Sem teogonias,

Sem parede nua

Para se encostar,

Sem cavalo preto

Que fuja à galope,

Você marcha, José!

José, para onde?

Nos dois poemas lidos é bem evidente a presença de questões próprias do existencialismo sartreanos, como a liberdade "sufocante" que culmina em uma profunda consciência da responsabilidade pela ideação de si e a angústia advinda dessa responsabilidade, como argumenta Sartre (1987, p. 13): 
O existencialista declara frequentemente que o homem é angústia. Tal afirmação significa o seguinte: o homem que se engaja e que se dá conta de que ele não é apenas aquele que escolheu ser, mas também um legislador que escolhe simultaneamente a si mesmo e a humanidade inteira, não consegue escapar ao sentimento de sua total e profunda responsabilidade.

O tom pessimista desses esboços de uma definição do humano reaparece em outro poema importante da obra drummondiana, que é "Um boi vê os homens" (Claro enigma), exercício ficcional que imagina um como se ardiloso: e se um boi pudesse falar como vê a nós, o que ele diria? Como pareceríamos a ele? Operando uma redução fenomenológica radical todas as características "humanas" são suspensas, e encena-se um "olhar outro", não humano, que pudesse nos dizer sem as armadilhas do antropocentrismo. Uma voz, reflexiva e ponderada, em exercício hermenêutico, já no primeiro verso nos define como "delicados", constatando logo a seguir que "falta-lhes qualquer atributo essencial" que, por sua ausência, traria como consequência uma "gravidade" que se confunde com o sinistro, bem como uma incapacidade de "enxergar o que é visível/e comum a cada um de nós, no espaço”. Incapacidade que teria como consequência certa tristeza que conduz à crueldade. $\mathrm{O}$ olhar bovino vai buscar entender a (nossa) "impossibilidade de se organizarem em formas calmas/permanentes e necessárias” relacionando-a a nossa constituição física frágil, com "pouca montanha”. Ainda assim, constata, sem muitas certezas, "certa graça melancólica” que faz perdoar "a agitação incômoda e o translúcido/ vazio interior”, sentimentos perturbadores que estariam na origem da linguagem ("sons absurdos e agônicos") e das paixões humanas ("desejo, amor, ciúme"). O que é interessante notar é que tais sons "se despedaçam/ e tombam no campo" "como pedras aflitas" que “queimam a erva e a água”. Mas, mais do que isso, esses sons - a linguagem humana - perturba também nosso eu lírico bovino, distraindo-o da ruminação da sua "verdade".

Em relação à proximidade dessa visão bovina sobre a humanidade e a concepção existencialista, o que mais chama a atenção é a constatação 
de uma fragilidade extrema - "mais que um arbusto"; "pobres e carecidos de emitir sons absurdos e agônicos” -, no sentido em que a cosmovisão sartreana é a de um mundo onde os valores precisam ser inventados, e não há outro para se responsabilizar por essa tarefa hercúlea se não o próprio homem, e esse não é em nenhum sentido um "super-homem", nem tem modelos heroicos ou divinos ${ }^{6}$ nos quais se apoiar, só a si e seu projeto de vida, precariedade que pode horrorizar alguns, que caracterizam o existencialismo de pessimista, acusação da qual Sartre (1987) se defende afirmando que o existencialismo é otimista, pois é "uma doutrina da ação" (p.48), sendo necessário que "o homem se reencontre e se convença de que nada pode salvá-lo dele próprio” (p. 48). Frágil é o humano diante do peso dessa responsabilidade de construir-se abdicando de ilusórias essências preexistentes, mas é onde mora a fraqueza que a força pode se manifestar ${ }^{7}$; é agindo "como se" determinada ação fosse a mais correta/adequada/ética que o homem contribui para que tais ações sejam universalizadas ("escolhe o homem"). É sentindo sobre si o peso das decisões que cotidianamente precisa tomar e, não usando de má-fé, assumindo que tais decisões são única e exclusivamente de sua competência, é que o homem se descobre livre (não sujeito à determinismos), livre para inventar um mundo outro, talvez melhor. O poema "Um boi vê os homens" não explicita tanto otimismo com o destino humano, entretanto, já que nele a linguagem sem dúvida uma das mais ricas manifestações da cultura humana - é tido como originada de nosso "vazio interior", há nele sim uma riqueza que nasce de nossa extrema penúria.

6 Sobre essa questão, Bornheim (2012, p. 5), analisando as contribuições do pensamento sartreano, afirma: "A estátua, mesmo que de gesso, inventa um homem pantomímico que acaba por patentear-se como falsificador da condição humana em si mesma. E é precisamente contra isso que se erguia toda a verve do maior moralista do século passado. A denúncia do que ele chama de má fé reside exatamente no fato de que o homem tende, num processo que se deixa emperrar nos passos da autofalsificação, a submeter-se ao outro, qualquer seja ele - um amado qualquer, um herói, o próprio Deus - como se esse outro devesse funcionar à maneira de um modelo."

7 Assim pensava o apóstolo Paulo, que afirma: "Por isso, por amor de Cristo, regozijo-me nas fraquezas, nos insultos, nas necessidades, nas perseguições, nas angústias. Pois, quando sou fraco, é que sou forte”. II Carta aos Coríntios 12, 10 - Bíblia Sagrada, p. 2186. 
“O TEMPO É BOA MEDIDA, /IRMÃos, VIVAMOS O TEMPO”

Do corpus de poemas selecionado, nos falta apenas "Os últimos dias" para comentar, e ele se inicia com a anunciação do encontro fatal com a "indesejada das gentes" -

Que a terra há de comer

- constatação que se faz acompanhar de uma adversativa que barra essa certeza, e encena o tempo do “ainda não”, quando há devir e vida, movimento febril de potência erótica e intelectiva:
Mas não coma já.
Ainda se mova,
para o ofício e a posse.

O tom reflexivo do poema se materializa no modo verbal subjuntivo, esse que exprime incerteza, dúvida ou condição, expressando ações que se anunciam como desejáveis (e possíveis), se bem que incertas, ações que não foram realizadas e que dependem de outras para acontecer. Praticamente todo o poema é o desenvolvimento argumentativo dos dois primeiros versos, ou seja, antes do termo final da existência, que isso e aquilo ocorram, um isso e aquilo detalhados com riqueza poética nos versos que se seguem. E essa lista de afazeres para o aquém-túmulo se inicia com a exploração sensível do mundo:

E veja alguns sítios

Antigos, outros inéditos.

Descubra em seu movimento

Forças não sabidas, contatos.

O prazer de estender-se; o de

Enrolar-se, ficar inerte.

Prazer de balanço, prazer de voo.

Prazer de ouvir música;

Sobre o papel deixar que a mão deslize.

Irredutível prazer dos olhos; 
Certas cores: como se desfazem, como aderem;

Certos objetos, diferentes a uma luz nova.

Que ainda sinta cheiro de fruta,

De terra na chuva, que pegue,

Que imagine e grave, que lembre.

Ao termo da qual procura-se estabelecer certa duração temporal para essa aventura que é ser humano, e ao mesmo tempo atualizar essa lista de ações irrecusáveis para esse estar-no-mundo que nos últimos versos se identificará com a composição Carlos Drummond de Andrade (à qual se dará um adeus sem adjetivos):

O tempo de conhecer mais algumas pessoas,

De aprender como vivem, de ajudá-las.

Mas é também tempo de "saber que alguns erros caíram, e a raiz/ da vida ficou mais forte", talvez por se ter descoberto "que somos todos irmãos, insisto", descoberta tão importante que será reiterada por quatro vezes no poema. Tempo em que se viva o tempo, e (se) possa

[...] despedir-me e contar que não espero outra luz além da que nos envolveu dia após dia, noite em seguida à noite, fraco pavio, pequena amplo fulgurante, facho lanterna, faísca, estrelas reunidas, fogo na mata, sol no mar, mas que essa luz basta, a vida é o bastante, que o tempo é boa medida, irmãos, vivamos o tempo.

Que seja esse tempo, “e não outro”, [...] sature a sala, banhe os livros, nos bolsos, nos pratos se insinue: com sórdidos ou potente clarão.

Continua-se com a "lista" de desejos para um tempo que se apresenta cúmplice de uma parte secreta a nós pertencente, no tempo, 
lista que se encadeia a partir da bela metáfora de uma abelha colhendo o mel dos domingos e, depois, resgatando algo íntimo e belo dos demais dias da semana:

E todo mel dos domingos se tire;

o diamante dos sábados, a rosa

de terça, a luz de quinta, a mágica

de horas matinais, que nós mesmos elegemos

para nossa pessoal despesa, essa parte secreta

de cada um de nós, no tempo.

Por fim, é da "hora esperada" que se fala, almejando-se "que não seja vil, manchada de medo,/ submissão ou cálculo". Ainda que nela haja "um elemento de dor", o sujeito poético reforça que não a quer

[...] negando as outras horas nem as palavras

ditas antes com voz firme, os pensamentos

maduramente pensados, os atos

que atrás de si deixaram situações.

E, os últimos versos são um longo e detalhado adeus à composição "que um dia se chamou Carlos Drummond de Andrade", incluindo tanto uma despedida às marcas corpóreas que esse deixará atrás de si - os sulcos profundos no travesseiro, a sombra no muro, os objetos de uso pessoal - quanto aos sinais abstratos, talvez mais frágeis e perecíveis, como as ideias de justiça e revolta. Enfatizando o aspecto construtivo disso que costumamos chamar individualidade, o eu lírico reconhece a importância da alteridade nessa construção de si, uma vez que essa é tanto uma "vida aos outros legada" quanto uma aventura conjunta em que "tudo, mas tudo é nosso irmão".

"A ESCURIDÃo ESTENDE-SE, MAS NÃO ELIMINA O SUCEDÂNEO DA ESTRELA NAS MÃOS.”: NOTAS PARA UMA CONCLUSÃO

O verso citado no subtítulo acima é do conhecido poema "Nosso tempo", do livro Rosa do povo (1945), considerado unanimemente a mais 
alta manifestação da poesia social de Drummond. Foi escrito "durante os anos cruciais da Segunda Guerra Mundial”, de modo que "as preocupações então reinantes são identificadas em muitos de seus poemas”, como nos diz o próprio Drummond em nota à publicação pela editora Record. Nos poemas desse livro, em especial, parece ressoar o imperativo sartreano de que "A literatura devia ser a obra de homens com uma visão clara, que consideram a totalidade da humanidade. A literatura deve ser consciente de que existe um mundo onde as crianças morrem de forme" ${ }^{8}$. Sobre o tempo desse poema citado, os versos iniciais, famosos, dizem:

Este é um tempo de partido, tempo de homens partidos.

A maior parte dos poemas lidos - com exceção apenas de "A suposta existência”, publicado no livro Claro Enigma em 1980 - estão inseridos nesse tempo "de partidos". Um Brasil que assistia atônito aos horrores da Segunda Guerra Mundial (ou as consequências dela) lá fora, e que aqui convivia com o Estado Novo e a polarização política. Um tempo em que o poeta constata que "As leis não bastam", pois "Os lírios não nascem da lei". Oculta, a precária síntese desafia o poeta à decifração, e ele se cala, e espera. Suas palavras, porém, se fazem ouvir através desse silêncio expectante, palavras duras e enérgicas que falam de resistência - Continuamos -, afinal "o sucedâneo da estrela nas mãos" nos promete que "Ainda é tempo de viver e contar” histórias - a minha, a sua, a nossa - pois essas não se perderam no tempo, mas são reencontradas na voz humílima da velha preta, do jornalista, do poeta, do pequeno historiador urbano. E o poeta, consciente de seu papel, conta-nos da fragmentação imputada pela lógica capitalista - na qual o "esplêndido negócio" "toma conta de tua alma e dela extrai uma porcentagem”. O poeta pede-nos então, ainda, que escutemos

[...] o horrível emprego do dia em todos os países de fala humana,

8 SARTRE apud GUIMARÃES, 2010, p. 43 
a falsificação das palavras pingando nos jornais,

o mundo irreal dos cartórios onde a propriedade é um bolo com flores, os bancos triturando suavemente o pescoço do açúcar,

a constelação das formigas e usurários,

a má poesia, o mau romance,

os frágeis que se entregam à proteção do basilisco,

o homem feio, de mortal feiura,

passeando de bote

num sinistro crepúsculo de sábado.

São esses os sons de um mundo e um tempo - vivamos o tempo, ele é a nossa medida, nos diz Drummond em outro poema - preenchido por "horrível" rotina (verso 1) de bancos ferozes, constelação de usurários e jornais mentirosos (não seria também esse o nosso tempo contemporâneo?). É também o som da família burguesa, no qual "a cama devora tua solidão", não obstante salve-se "a honra e a herança do gado". Sim, há bálsamos, variados em forma e figura, e há o artifício do recalque das "dores ignóbeis", mas a face trocista do poeta emerge de dentro do nosso pranto, e "ri e despreza" nossos bálsamos e nossas dores - por teatrais demais? - ainda que pareça compartilhar conosco a reprovação e o desgosto "desse chapéu velho, da rua lodosa, do Estado". Decididamente, ao poeta repugna todo lirismo deteriorado, talvez por vinculá-lo a uma ordem que abomina e a qual promete ajudar

a destruí-lo

como uma pedreira, uma floresta um verme.

Com as "suas palavras, intuições, símbolos e outras armas", mas principalmente com as suas palavras, Drummond leva a cabo o imperativo sartreano de que o escritor deve estar comprometido com o seu tempo, até por saber que estamos sempre "irremediavelmente comprometidos" com o nosso tempo (LEOPOLDO E SILVA, 2013), afinal, a não escolha já é uma escolha. E o poeta Drummond soube declinar "de toda responsabilidade/na marcha do mundo capitalista”. 


\section{DRUMMOND AND EXISTENTIALISM}

\section{Abstract}

The article proposes the directed reading of a corpus of selected poems by Carlos Drummond de Andrade, in which, with no pretension of a totalizing interpretation of his work, we seek to understand themes, subjects and figures akin to existentialist philosophy as disseminated by Jean-Paul Sartre. The conclusion reached is that, although it is not possible to identify direct influences of existentialism in Drummond's poetry, there are common themes and approaches between his poetry and existentialism mainly with regard to the understanding of a radical temporality proper to man allied to the exile of freedom, which makes him a persona of his time and a builder of himself.

KeYwords: Carlos Drummond de Andrade. Existentialism. Poetry Jean-Paul Sartre.

\section{DRUMMOND Y EL EXISTENCIALISMO}

\section{RESUMEN}

El artículo es una lectura dirigida de un corpus de poemas seleccionados de Carlos Drummond de Andrade, en el que, sin pretensiones de una interpretación totalizadora de su obra, busca comprender temas, sujetos y figuras relacionados con la filosofía existencialista, tal como los difunde Jean Paul. Sartre. La conclusión a la que se llega es que, si bien no es posible identificar influencias directas del existencialismo en la poesía de Drummond, existen temas y enfoques comunes entre su poesía y la misma, especialmente en lo que se refiere a la comprensión de una temporalidad radical propia del hombre aliada al exilio de la libertad, que lo convierte en persona de su tiempo y constructor de sí mismo.

Palabras-clave: Carlos Drummond de Andrade. Existencialismo. Poesía. Jean-Paul Sartre.

\section{REFERÊNCIAS}

BATAILLE, George. O erotismo. Porto Alegre: L\&PM Editores, 1987. 
BARROS, Manoel de. O livro das ignorãças. Rio de Janeiro: Alfaguarra, 2016.

BERNARDO, Gustavo. A dúvida de Flusser. São Paulo: Globo, 2002.

BÍBLIA, N.T. II Carta aos Coríntios. In: BÍBLIA DE JERUSALÉM. São Paulo: Edições Paulinas, 1985.

BORNHEIM, Gerd. Sartre revisto. Rapsódia, n. 6, p. 13-19, 2012. Disponível em: https://www.revistas.usp.br/rapsodia/article/view/106534 Acesso em: 18 maio 2021.

BOSI, Alfredo. História concisa da literatura brasileira. São Paulo: Cultrix, 2006.

CANÇADO, José Maria. Os sapatos de Orfeu. São Paulo: Globo, 2012.

CHAUÍ, Marilena. Convite à filosofia. São Paulo: Ática, 2003.

GUIMARAES, Frederico Moreira. Literatura e engajamento em Sartre: um estudo de Que é a literatura? 2010. Dissertação (Mestrado) - Pontifícia Universidade de São Paulo, São Paulo, 2010.

FRANKE, William. On what cannot be said: apophatic discourses in philosophy, religion, literature, and the arts. Indiana: University Notre Dame Press, 2007. (v. 1).

HEIDEGGER, Martin. Arte y poesia. Prólogo y traducción Samuel Ramos. México: FCE, 2006.

HEIDEGGER, Martin. A caminho da linguagem. Petrópolis: Editora Vozes, 2003. HEIDEGGER, Martin. Ensaios e conferências. Petrópolis: Editora Vozes, 2001.

LEOPOLDOESILVA, Franklin.Fenomenologiaeexistencialismo.2013.Disponível em: https://institutocpfl.org.br/play/fenomenologia-e-existencialismo-franklinleopoldo-e-silva/ Acesso em: 06 maio 2021.

LEOPOLDO E SILVA, Franklin. Sartre: liberdade e compromisso. Cult, 2010. Disponível em: https://revistacult.uol.com.br/home/liberdade-ecompromisso/ Acesso em: 7 dez. 2021.

MONTEIRO, Walmir dos Santos. "Nada no bolso ou nas mãos": influências do existencialismo sartreano na contracultura brasileira 1960-1970. 2007. Orientador: José Augusto dos Santos. Dissertação (Mestrado) - Universidade Severino Sombra, Vassouras, 2007.

PAZ, Octávio. O arco e a lira. Rio de Janeiro: Nova Fronteira, 1982. 
PRADO JR, Bento. Sartre nos trópicos: entrevista concedida a Cauê Alves. Revista Trópico, São Paulo, 2014.

SANT'ANNA, Affonso Romano de. Drummond: o gauche no tempo. Rio de Janeiro: Record, 1992.

SARTRE, Jean-Paul. Uma ideia fundamental da fenomenologia de Husserl: a Intencionalidade. Tradução Ricardo Leon Lopes. Veredas FAVIP, Caruaru, v. 2, n. 1, p. 102-107, jan./jun. 2005.

SARTRE, Jean-Paul. O existencialismo é um humanismo. Tradução Rita Correia Guedes. São Paulo: Nova Cultural, 1987.

Submetido em 18 de agosto de 2021

Aceito em 16 de novembro de 2021

Publicado em 30 de janeiro de 2022 